\title{
DNA vaccines targeting the encoded antigens to dendritic cells induce potent antitumor immunity in mice
}

\author{
Jun Cao ${ }^{1 \dagger}$, Yiqi Jin ${ }^{2 \dagger}$, Wei $\mathrm{Li}^{3 \dagger}$, Bin Zhang ${ }^{4}$, Yang He${ }^{1}$, Hongqiang Liư ${ }^{1}$, Ning Xia ${ }^{1}$, Huafeng Wei ${ }^{5^{*}}$ and Jian Yan ${ }^{{ }^{*}}$
}

\begin{abstract}
Background: Although DNA vaccine holds a great potential for cancer immunotherapy, effective long-lasting antitumoral immunity sufficient to induce durable responses in cancer patients remains to be achieved. Considering the pivotal role of dendritic cells (DC) in the antigen processing and presentation, we prepared DC-targeting DNA vaccines by fusing tumor-associated antigen HER2/neu ectodomain to single chain antibody fragment (scFv) from NLDC-145 antibody specific for DC-restricted surface molecule DEC-205 (scFv ${ }^{\text {NLDC-145) }}$, and explored its antitumoral efficacy and underlying mechanisms in mouse breast cancer models.

Results: In vivo targeting assay demonstrated that scFv ${ }^{N L D C-145}$ specifically delivered DNA vaccine-encoded antigen to DC. Compared with untargeted HER2/neu DNA vaccines, vaccination with scFvLDC-145-HER2/neu markedly promoted the HER2/neu-specific cellular and humoral immune responses with long-lasting immune memory, resulting in effective protection against challenge of HER2/neu-positive D2F2/E2 breast tumor while ineffective in parental HER2/neu-negative D2F2 breast tumor. More importantly, in combination with temporary depletion of regulatory $T$ cells (Treg) by low-dose cyclophosphamide, vaccination with scFv NLDC-145-HER2/neu induced the regression of established D2F2/E2 breast tumor and significantly retarded the development of spontaneous mammary carcinomas in transgenic BALB-neuT mice.

Conclusion: Our findings demonstrate that DC-targeted DNA vaccines for in vivo direct delivery of tumor antigens to DC could induce potent antigen-specific cellular and humoral immune responses and, if additional combination with systemic Treg depletion, was able to elicit an impressively therapeutic antitumoral activity, providing a rationale for further development of this approach for cancer treatment.
\end{abstract}

Keywords: DNA vaccine, DC-targeted, HER2/neu, Breast cancer, Cyclophosphamide

\section{Background}

During the last 20 years, DNA-based immunization has been rapidly developed as a new approach to prime specific cellular and humoral immune responses to protein antigens [1]. In mouse models, DNA vaccines have been successfully directed against many types of tumor with tumor protection reproducibly observed in an antigenspecific manner [2]. However, conventional DNA vaccines

\footnotetext{
* Correspondence: foxp3_smmu@163.com; yanjianvv@gmail.com ${ }^{\dagger}$ Equal contributors

5 International Joint Cancer Institute, Second Military Medical University, Shanghai 200433, China

'Interventional Oncology, Dahua Hospital, Xuhui District, Shanghai 200237, China

Full list of author information is available at the end of the article
}

with only the encoded antigen failed to mount an effective T-cell immunity in human trials, even when delivered by in vivo electroporation, which calls for a novel design for DNA vaccine $[1,2]$.

It is critical for DNA vaccination to be successful that encoded proteins are taken up, processed, and presented by dendritic cells (DC), the most potent antigenpresenting cells (APC) in vivo that initiate the adaptive immunity. Following intradermal or intramuscular injection of a plasmid DNA vaccine in mice, the encoded gene is expressed in transfected keratinocytes and myocytes at the site of injection [3] as well as a small number of DC [4-6]. Keratinocytes and myocytes are poorly effective in presenting antigen and priming naive immune cells due to lack of expression of MHC class II

\section{Biomed Central}


and costimulatory molecules, and do not have ready access to T cells in lymphoid tissues, as is the case for DC [7]. It is thought that transduced DC initiate immune priming process, which can be further boosted by antigen released from other long-lived transfected cells $[8,9]$. Therefore, targeting DNA vaccines to DC should improve the efficacy of DNA vaccines. In fact, a recent study demonstrated that DC-targeted DNA vaccines elicited much higher level of antibody and antigenspecific $\mathrm{T}$ cells, leading to effective protection against virus expressing encoded antigen [10].

Coupling of antigens to ligands or antibodies that specifically bind to DC receptors has been widely used as a means of DC targeting [11]. Using this approach, a lowered requirement for antigen dose in stimulating immune responses in mice has been observed after targeting a variety of molecules, including MHC class II, DEC205, CD11c, Dectin-1/2, mannose receptor, and CD36 [12-17]. The studies have also shown that antibodies specific for the mannose receptor or DC-SIGN could effectively deliver antigen to human DCs, indicating that this strategy may also be applicable to human vaccination $[18,19]$.

Overexpression of the HER-2 receptor tyrosine kinase has been found in various human malignancies, including breast, ovarian and gastric carcinomas, non-small cell lung cancer, and salivary gland cancers, and has been associated with poor prognosis of patients [20,21]. Endogenous HER2-specific CD4 ${ }^{+} \mathrm{T}$ cells and antibodies have been detected in patients with HER2-expressing cancers $[22,23]$, and in clinical trials, HER2-specific $\mathrm{CD} 4^{+}$and $\mathrm{CD}^{+} \mathrm{T}$-cell responses could be induced by peptide vaccination $[24,25]$. These studies provide strong supports for HER2 being an important tumor antigen for targeted immunotherapy. The clinically approved HER2-targeted immunotherapy involves infusion of humanized HER2specific monoclonal antibody Herceptin; ref. [26]. Although Herceptin has been shown to be effective in inhibiting tumor growth in a limited population of HER2postive metastatic breast cancer patients, elicitation of an active and more comprehensive immune response that includes both antibody and T-cell responses may provide more effective protection [27].

Here, we prepared DC-targeting DNA vaccines by fusing tumor-associated antigen HER2/neu ectodomain (HER2/neu, residues 22 to 561 or 22 to 582) to single chain antibody fragment (scFv) from NLDC-145 $\left(\mathrm{scFv}^{\mathrm{NLDC}-145}\right)$, a monoclonal antibody binding the mouse DC-restricted surface molecule DEC-205, and evaluated the preventive and therapeutic effects of these DNA vaccines in HER2/neu-positive mouse breast tumor models. We further characterized the cellular mechanisms driving antitumor effect of DC-targeted DNA vaccines elucidating the basic processes necessary to achieve immune-mediated tumor rejection.

\section{Methods \\ Mice and cell lines}

Six to 8-week-old female BALB/c $\left(\mathrm{H}-2^{\mathrm{d}}\right)$ mice were purchased from the Animal Experimental Center of the Second Military Medical University. BALB-neuT mice $\left(\mathrm{H}-2^{\mathrm{d}}\right)$ expressing a transforming neu under the control of mouse mammary tumor virus promoter were obtained from Charles River Laboratories (Shanghai, China). Heterozygous 6- to 15-week-old virgin females expressing rat neu as verified by PCR were used throughout this work. All animal studies were approved by the Institutional Review Board of the Second Military Medical University, Shanghai, China.

Mouse thymoma cell line EL4, breast cancer cell line 4 T1, and 293 T cell line were purchased from ATCC (American Type Culture Collection, VA, USA). The cells were maintained in DMEM supplemented with $10 \%$ FCS, $4 \mathrm{mmol} / \mathrm{L}$ glutamine, 100 units $/ \mathrm{mL}$ penicillin and $100 \mu \mathrm{g} / \mathrm{mL}$ streptomycin. D2F2/E2 and EL4/E2 stably expressing human wild-type HER2 were maintained in complete DMEM medium containing $0.4 \mathrm{mg} / \mathrm{mL}$ G418 (Sigma-Aldrich). TUBO cells are neu-expressing breast carcinoma cells established from a lobular carcinoma of a female BALB-neuT mouse [28], and maintained in DMEM containing 20\% FCS. Murine lymphocytes were cultured in RPMI-1640 containing 10\% FCS, 2 mmol/L glutamine and $50 \mu \mathrm{mol} / \mathrm{L} 2$-mercaptoethanol. All tissue culture reagents were purchased from Life Technologies unless described otherwise.

\section{Reagents}

Peptides used in this study were obtained from SigmaAldrich. All peptides were $>95 \%$ pure as indicated by analytical HPLC. Lyophilized peptides were diluted in DMSO and stored at $-20^{\circ} \mathrm{C}$ until use. Recombinant HER2 and TRP2 protein were purchased from R\&D Systems. Cyclophosphamide (CTX) were obtained from Sigma-Aldrich and reconstituted in sterile PBS $(20 \mathrm{mg} /$ $\mathrm{mL}$ ) for in vivo injections. Monoclonal antibodies (mAbs) to the following antigens were purchased from eBiosciences (San Diego, CA): CD4 (GK 1.5) and CD8 (53-6.7) conjugated to fluorescein isothiocyanate (FITC); CD11c (N418) and Foxp3 (FJK-16 s) conjugated to phycoerythrin (PE); mAbs to PE-TNF- $\alpha$ (MP6-XT22) and PE-IFN- $\gamma$ (XMG1.2) were purchased from BD PharMingen (San Jose, CA). Immunoglobulins with isotypes corresponding to the above mAbs and conjugated to the appropriate fluorochromes, were used as control for nonspecific binding. 


\section{Construction of DNA vaccines}

The backbone for the construction of DNA vaccines was the mammalian expression vector pcDNA3.1 (Invitrogen). In this vector encoding vaccine proteins are expressed under the control of the CMV promoter as an in-frame fusion with an antibody kappa chain signal peptide (SP) sequence (amino acid MDFQVQIFSFLLISASVIISRG) for secretion and are followed by C-terminal His tag for detection. The genes encoding the variable regions of the heavy $(\mathrm{VH})$ and light $(\mathrm{VL})$ chains of $\mathrm{scFv}^{\mathrm{NLDC}-145}$ were synthesized according to the published sequences [29]. Each VH fragment was bound to its VL partner by use of a spacer encoding a 15 amino-acid flexible linker $\left(\mathrm{Gly}_{4} \mathrm{Sert}\right)_{3}$, yielding scFv constructs scFv ${ }^{\mathrm{NLDC}-145}$. The sequence encoding for the extracellular domain of human HER2 or its rat homologue neu was amplified from cDNA of SK-BR-3 and TUBO cell lines using the following primers HER2-HindIII-s 5'-TTAAGCTTAG CACCCAA GTGTGCACCGGCAC-3', HER2-XbaI-as 5' -TTTCTAG ACAAACAGTGCCTGGCATT CACATAC-3' and neuHindIII-s 5'-TTAAGCTTGGAGCCGCGGGTACCCAA GTGTG-3', neu-XbaI -as 5'-TTTCTAGATCCAAAGCA GGTCTCTGAGCTGTTTTGAG-3'. The resultant encoding sequences were then cloned in-frame downstream of the $\mathrm{scFv}^{\mathrm{NLDC}-145}$. For in vivo targeting assay, we generated pcDNA3.1-scFv ${ }^{\mathrm{NLDC}-145}$-EGFP by replacing the HER2 fragment with EGFP sequence cloned from pEGFP-N1 plasmid. The pcDNA3.1 vector encoding EGFP without DC-targeting scFv fragments as controls (pcDNA3.1 and pcDNA3.1-EGFP).

\section{Expression of protein encoded by DNA vaccines}

The different pcDNA3.1 constructs were transiently transfected in 293T cells using Lipofectamine 2000 according to the manual instruction (Invitrogen). The resultant supernatants were harvested at 72 hours posttransfection and concentrated and dialyzed using centrifugal filter devices (Amicon Ultra, 10K, millipore). Protein expression was analyzed by Western blotting using recombinant anti-His mAb (ab1187, Abcam).

\section{In vivo targeting assay}

The $50 \mu \mathrm{g}$ pcDNA3.1-scFv ${ }^{\mathrm{NLDC}-145}$-EGFP and pcDNA3.1EGFP plasmids in $50 \mu \mathrm{L}$ PBS were injected into the upper leg muscle of the left hind limb of the mice followed by in vivo electroporation as described previously [30]. One day later, the lysate of the muscle tissues of injection site were prepared using RIPA buffer and subjected to the western blotting for detection of EGFP and $\mathrm{scFv}^{\mathrm{NLDC}-145}$ EGFP fusion protein by anti-EGFP antibody (ab111258, Abcam) as described above. The spleens were harvested from the injected mice at different time points $(48,60$, 72 hours) and single-cell suspensions were prepared and stained with PE-conjugated anti-CD11c antibody or isotype control for $30 \mathrm{~min}$. The GFP fluorescence in the CD11c-positive DC was analyzed by flow cytometry as described previously [14].

\section{Protective and therapeutic vaccination}

For prophylactic vaccination, female $\mathrm{BALB} / \mathrm{c}$ mice or BALB-neuT mice were vaccinated on days -21 and -7 by intramuscular injections of $50 \mu \mathrm{g}$ pcDNA3.1scFv $^{\mathrm{NLDC}-145}$-HER2/neu, pcDNA3.1-HER2/neu plasmid DNA in $50 \mu \mathrm{L}$ PBS as described above. As control, $50 \mu \mathrm{L}$ pcDNA3.1 or $50 \mu \mathrm{L}$ PBS were injected. On day 0 , animals were inoculated subcutaneously (s.c.) with $2 \times$ $10^{5}$ D2F2/E2, D2F2 or TUBO tumor cells in the opposite flank. Tumor growth was monitored with a caliper by measuring two perpendicular tumor diameters every week, and tumor volumes were calculated according to the formula: length $\times(\text { width })^{2} \times 0.5$. For therapeutic vaccination, when the tumors were $3-4 \mathrm{~mm}$ in diameter (day 7), mice were injected intraperitoneally (i.p.) with cyclophosphamide $(100 \mathrm{mg} / \mathrm{kg})$ in $100 \mu \mathrm{L}$ PBS. Four days later (day 11), animals were vaccinated as described above. Vaccination was repeated once 14 days later, and tumor growth was followed. If animals appeared moribund or the diameter of the tumors reached $15 \mathrm{~mm}$, the mice were sacrificed and this was recorded as the date of death for survival studies. For rechallenging experiments, the long-term surviving mice were injected s.c. either with $2 \times 10^{5}$ D2F2/E2, D2F2, or 4T1 tumor cells.

\section{Prevention of spontaneous tumors}

Preventive effects of the DNA vaccines were investigated in virgin female BALB-neuT mice that endogenously express neu in their mammary glands and develop neu-driven mammary carcinomas [28]. Animals were immunized twice at 8 and 10 week ages as described above. Mammary glands were inspected every week to monitor the appearance of tumors. Measurable/ palpable masses $>2 \mathrm{~mm}$ in diameter were regarded as tumors. Data are reported as tumor multiplicity (cumulative number of tumors per number of mice in each group) and shown as mean \pm SE.

\section{Cytometric identification of regulatory $\mathrm{T}$ cells}

For detection of regulatory $\mathrm{T}$ cells (Treg), splenocytes from immunized mice were surface stained with FITC anti-mouse CD4 (GK1.5; eBioscience). After that, cells were washed with wash buffer (PBS with $1 \%$ fetal bovine serum and $0.09 \%$ sodium azide), fixed and permeabilized with the Cytofix/Cytoperm reagent (BD Bioscience) for 20 minutes at $4^{\circ} \mathrm{C}$, after which they were washed in Perm/Wash buffer (BD Bioscience), and stained with PE anti-mouse Foxp3 (FJK-16 s; eBioscience) at $4^{\circ} \mathrm{C}$ for 30 minutes. Immunoglobulin G-PE and immunoglobulin G-FITC (mouse) were used as negative controls. All 
analysis was performed on the FACSCalibur (Becton Dickinson) flow cytometer.

\section{Evaluation of T-cell responses}

For detection of HER2-specific cellular immune response, splenocytes from vaccinated mice were cultured in 96-well flat-bottomed plates in $100 \mu \mathrm{L}$ of growth medium in the presence of $10 \mu \mathrm{g} / \mathrm{mL}$ recombinant HER2 or TRP2 protein in vitro. After $80 \mathrm{~h},\left[{ }^{3} \mathrm{H}\right]$ thymidine $(1 \mu \mathrm{Ci} /$ well; Amersham) was added for the remaining $16 \mathrm{~h}$ of the assay. $\left[{ }^{3} \mathrm{H}\right]$ thymidine incorporation was analyzed by liquid scintillation counting as described previously [14]. The supernatants were also collected and assayed for production of IFN- $\gamma$, TNF- $\alpha$, IL-4, IL-10 by ELISA kits (R\&D Systems).

For detection of IFN- $\gamma$ and TNF- $\alpha$-producing CD4 or CD8 $\mathrm{T}$ cells, intracellular cytokine staining assays were performed. Briefly, splenocytes harvested from vaccinated mice were cultured in the presence of $10 \mu \mathrm{g} / \mathrm{mL}$ recombinant HER2 or TRP2 protein for $24 \mathrm{~h}$. During the final $4 \mathrm{~h}$ of incubation, $10 \mu \mathrm{g} / \mathrm{mL}$ brefeldin A were added. After surface staining with FITC-CD4 and FITC-CD8, cells were permeabilized and stained with PE-IFN- $\gamma$ and PE-TNF- $\alpha$ prior to analysis by flow cytometry as described above. For CTL measurements, ${ }^{51} \mathrm{Cr}$-release assays were performed as described previously [14].

\section{Analysis of antibody responses}

Peripheral blood was collected from the tail vein of the mice, and 1:100 dilutions of sera were analyzed by ELISA with recombinant HER2 protein or by flow cytometry using D2F2/E2 and TUBO tumor cells as described previously [14]. Normal mouse serum served as negative control.

\section{Statistical analysis}

Differences among tumor growth kinetics, tumor multiplicity, and specific cytotoxicity were evaluated by ANOVA or the Student's test. Values of $\mathrm{P}<0.05$ were considered significant. For survival studies, Kaplan-Meier survival curves were plotted and analyzed using Prism 5.00 software (GraphPad Software).

\section{Results}

\section{Construction and expression of DNA vaccines}

We obtained the genes encoding $\mathrm{scFv}^{\mathrm{NLDC}-145}$ by whole gene synthesis according to the published sequences [29]. The carboxyl terminus of the $\mathrm{scFv}^{\mathrm{NLDC}-145}$ was directly fused in-frame to the sequences encoding the extracellular domain of HER2 (amino acids 22-561) or neu (amino acids 22-582) amplified from SK-BR-3 or TUBO breast cell lines, followed by His tag (Figure 1A). To confirm the expression of these constructs, 293T cells were transiently transfected with these plasmids, and then supernatants were harvested 72 hours later and tested for protein secretion by Western blotting. As shown in Figure 1B, we detected the production of $\mathrm{scFv}^{\mathrm{NLDC}-145}$-HER2 and $\mathrm{scFv}^{\mathrm{NLDC}-145}$-neu proteins (lane 1,2 ) or HER2 and neu fragments (lane 3,4 ) in the supernatants by anti-His tag antibody respectively, and their molecular weights were slightly larger than predicted, indicating certain extent of glycosylation.

\section{SCFv ${ }^{\text {NLDC-145 }}$ targets antigen to DC in vivo}

To test whether $\mathrm{scFv}^{\mathrm{NLDC}-145}$ moiety delivery encoded antigens into DC in vivo, we constructed pcDNA3.1-

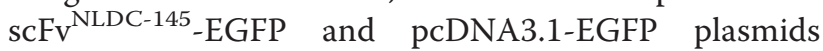
(Additional file 1: Figure S1), which facilitated us to trace the final fate of antigens carried by $\mathrm{scFv}^{\mathrm{NLDC}-145}$. The animals were injected i.m. with scFv ${ }^{\mathrm{NLDC}-145}$-EGFP plasmids, sacrificed at different time points postinjection, and splenocytes were harvested and probed for GFP fluorescence by flow cytometry. We first confirmed the comparative expression of EGFP and $\mathrm{scFv}^{\mathrm{NLDC}-145}$-EGFP fusion protein with correct molecular weight in the muscle tissue of injection site by western blotting (Figure 1C, right). As shown in Figure 1D, approximate $50 \%$ CD11c-positive DC in the spleen from pcDNA3.1-scFv ${ }^{\text {NLDC-145 }}$-EGFP-treated animals showed GFP fluorescence at $48 \mathrm{~h}$ post-injection, and this percentage further went up, approaching about $65 \%$ at $60 \mathrm{~h}$ post-injection. Antigen loading was DCspecific since CD11c-negative non-DC cells showed few, if any, GFP fluorescence. A representative dot plot obtained at $60 \mathrm{~h}$ post-injection was shown in Figure 1C, left. In contrast, after injection of pcDNA3.1-EGFP plasmid, some fluorescence slightly above background levels were detectable, resulting in only $10 \%$ of DC being loaded (background level was 5\%). The much lower percentage of GFP-positive DC in pcDNA3.1-EGFPtreated mice was not due to lower GFP expression efficiency of pcDNA3.1-EGFP plasmid since total GFPpositive cells in splenocytes were almost same from mice receiving injection of these two constructs.

\section{Protection of mice from challenge with HER2-expressing tumor cells}

To investigate whether immunization with DC-targeted vaccines induce antitumoral immunity and protect animals from subsequent tumor challenge, BALB/c mice were i.m. vaccinated twice at two week interval with various vaccines. Seven days after last immunization, the mice were subcutaneously challenged with HER2positive D2F2/E2 tumor cells, and tumor development was monitored. As shown in Figure $2 \mathrm{~A}, \mathrm{scFv}^{\mathrm{NLDC}-145}$ HER2 vaccination protected mice from D2F2/E2 tumor challenge, resulting in $100 \%$ survival in all mice during the observation period (120 days after vaccination). 
A

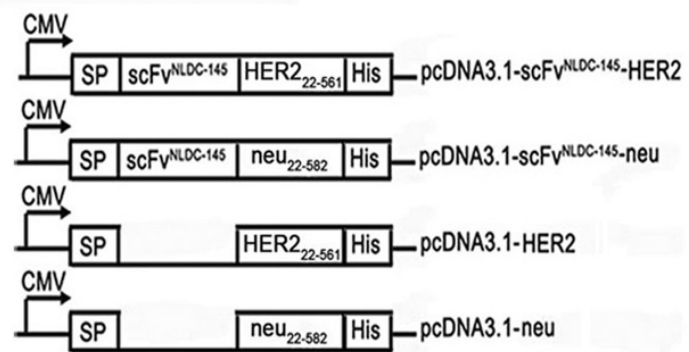

C

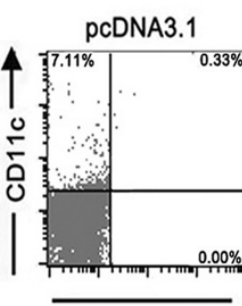

.

GFP Fluorescence

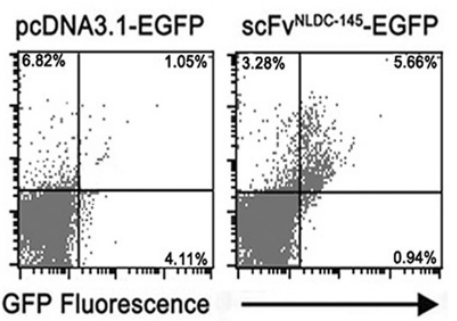

B

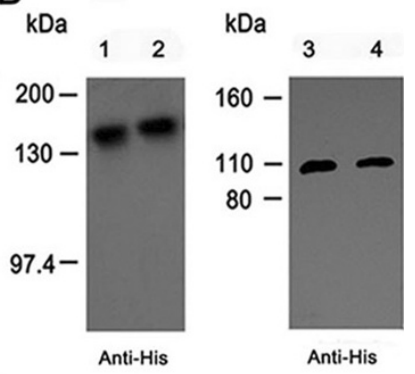

kDa

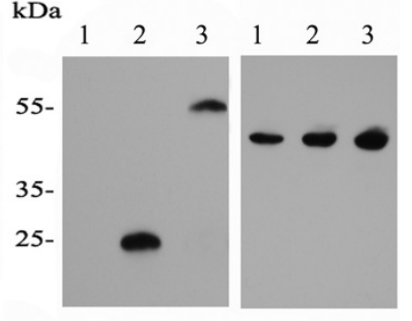

EGFP

D
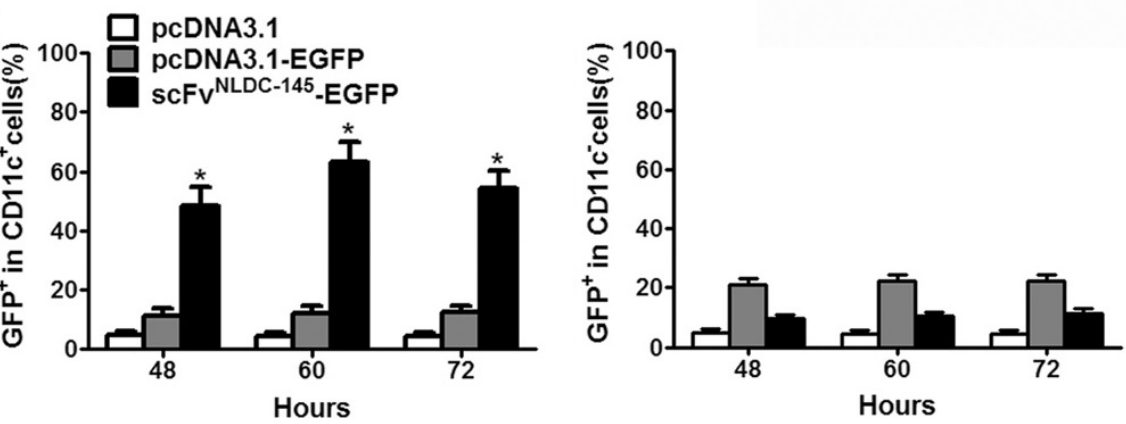

Figure 1 scFv ${ }^{\text {NLDC-145 }}$ targets tumor antigen into DCs in vivo. A schematic representation of expression vectors. SCFV NLDC-145-HER2, scFV NLDC-145 neu, pcDNA3.1-HER2, or pcDNA3.1-neu encode under the control of a CMV promoter, all the fusion proteins consisting of an signal peptide, amino acid residues 22 to 561 of human HER2 or amino acid residues 22 to 582 of rat neu, and COOH-terminal His tag. The control plasmids pcDNA3.1-HER2 and pcDNA3.1-neu lack the NLDC-145 domains. B 293T cells grown in 100-mm dishes were transfected with various expression vectors using

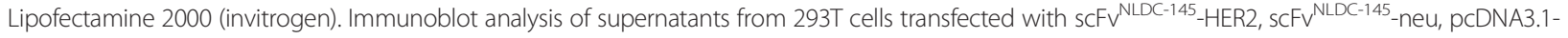
HER2 and pcDNA3.1-neu (lane 1,2,3 and 4). Vaccine proteins were probed with mouse anti-His tag mAb followed by HRP-conjugated secondary antimouse antibody. C left, scFv NLDC-145-EGFP plasmid and controls as indicated were injected i.m. into mice, spleens were removed 48, 60, and $72 \mathrm{~h}$ thereafter, and stained with PE-conjugated anti-CD11c antibody. The GFP fluorescence in splenocytes was measured by flow cytometry. Representative results from one animal of each group $60 \mathrm{~h}$ post-injection. right, the expression of EGFP (MW, 25 kDa) and scFv NLDC-145-EGFP $(\mathrm{MW}, \sim 55 \mathrm{kDa}$ ) fusion protein in injected muscle tissues detected by western blotting using anti- EGFP antibody $24 \mathrm{~h}$ after plasmid injection with GAPDH (MW,42 kDa) as loading control. Lane 1, mice treated with pcDNA3.1 control vaccine; lane 2, mice treated with EGFP-encoding vaccine; lane 3, mice treated with scFv ${ }^{\mathrm{NLDC}-145}$-EGFP vaccine; $\mathbf{D}$ percentages of GFP ${ }^{+}$DC in total DC (left panel); Percentages of GFP ${ }^{+}$in CD11cnegative splenocytes (right panel). Bars, SE. *, P $<0.01$, scFv ${ }^{\text {NLDC-145 }}$ EGFP compared with other groups.

Furthermore, animals treated with $\mathrm{scFv}^{\mathrm{NLDC}-145}$-neu exhibited slower tumor growth compared with those treated with untargeted HER2 or neu DNA vaccine or control pcDNA3.1, resulting in prolonged survival of these mice, which indicated the induction of crossreactivity toward HER2 antigen by $\mathrm{scFv}^{\mathrm{NLDC}-145}$-neu vaccination. To examine whether HER2-specific responses induced by $\mathrm{scFv}^{\mathrm{NLDC}-145}$-HER2 vaccines were responsible for protection, a similar experiment was done using parental HER2-negative D2F2 tumor cells. Rapid tumor growth was observed in all animals regardless of either treatment (Figure 2B), suggesting that antitumor activity against HER2-expressing D2F2/E2 tumor cells was due to HER2-specific immune responses induced by $\mathrm{scFv}^{\mathrm{NLDC}-145}$-HER2. We also obtained a similar protective effect of $\mathrm{scFv}^{\mathrm{NLDC}-145}$-HER2 in C57BL/6 mice using paired EL/4 and EL4/E2 tumor models (data not shown).

To test whether immunologic memory was developed, long-term surviving mice initially vaccinated with $\mathrm{scFv}^{\mathrm{NLDC}-145}$-HER2 were rechallenged with D2F2/E2 tumor cells. The parental D2F2 cells or unrelated 

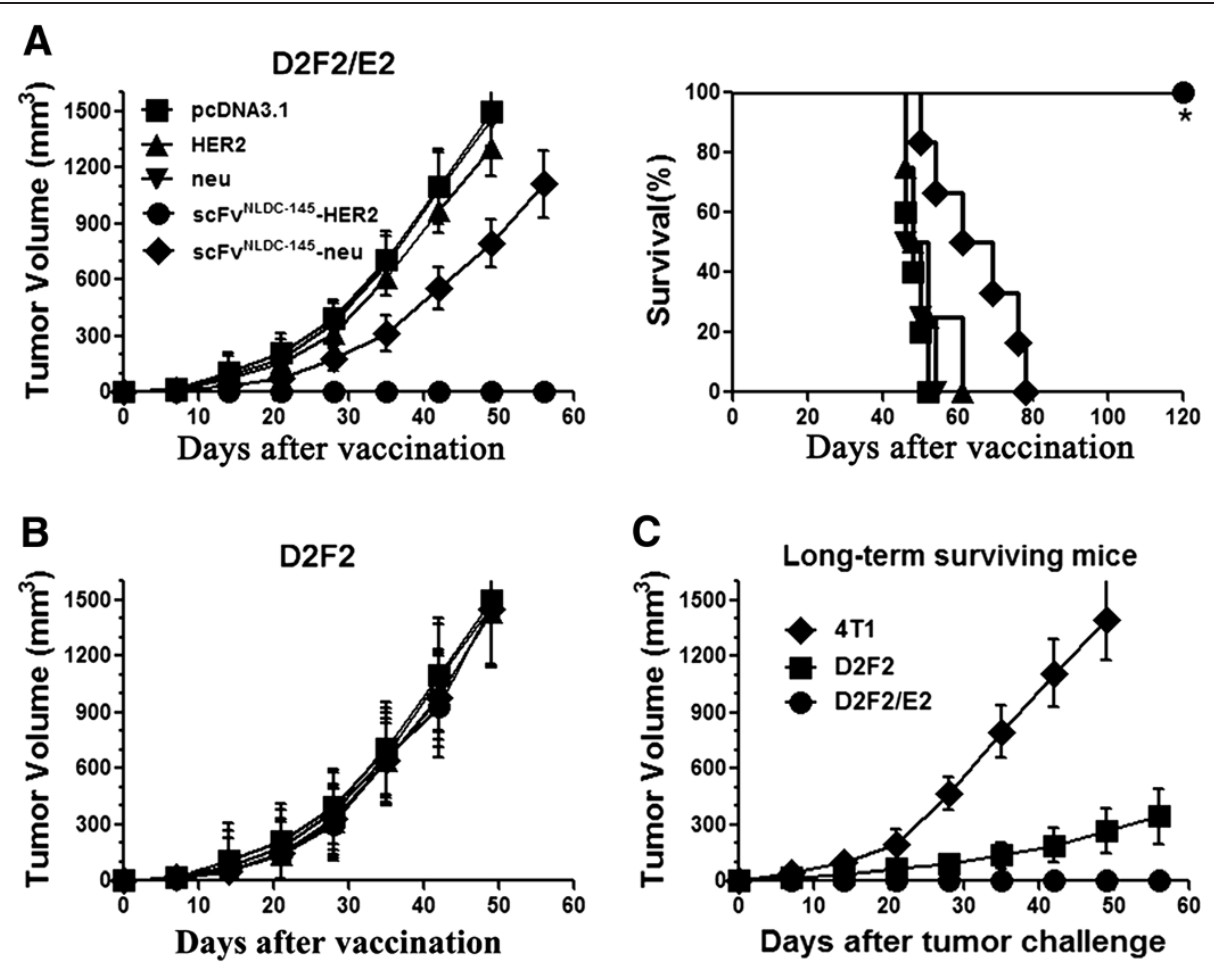

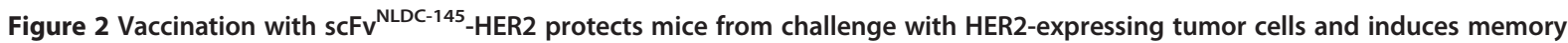
immune responses. A animals (10 mice per group) were vaccinated with HER2, neu, scFv NLDC-145-HER2 or scFv ${ }^{\text {NLDC-145 }}$-neu on days -21 and -7 . Control animals received pcDNA3.1. On day 0, mice were inoculated s.C. with D2F2/E2 tumor cells. Tumor developments were monitored, and animal survival was calculated. Left panel, kinetics of tumor growth; Right panel, survival curve. B the vaccinated animals were challenged with parental HER2-negative D2F2 cells on day 0. C the long-term surviving mice from SCFv NLDC-145-HER2 group were rechallenged with D2F2/E2, D2F2, or syngeneic unrelated 4 T1 tumor cells 3 months after initial tumor challenge. Tumor growth was followed. Bars, SE. *, P < 0.001, sCFV NLDC-145-HER2 compared with other groups.

syngeneic $4 \mathrm{~T} 1$ cells were used as controls. As shown in Figure $2 \mathrm{C}$, the mice rejected subsequent rechallenges with the D2F2/E2 tumor cells and remained tumor-free, however, the mice could not reject unrelated syngeneic 4. T1 tumor. Interestingly, mice were also resistant to the rechallenge with the parental D2F2 tumor cells with 70\% of mice tumor-free and remaining mice displaying drastically slow tumor growth. In summary, these results indicate that $\mathrm{ScFv}{ }^{\mathrm{NLDC}-145}$-HER2 vaccination induced long-lasting HER2-specific antitumor immunity, which could protect mice from HER2-expressing tumor challenge.

\section{Induction of HER2-specific T cells}

To analyze the nature of the immune responses induced by $\mathrm{scFv}^{\mathrm{NLDC}-145}$-HER2, splenocytes were isolated from the vaccinated mice and cultured in the presence of recombinant HER2 or TRP2 protein for 3 days in vitro. As shown in Figure 3A, left, splenocytes obtained from $\mathrm{scFv}^{\mathrm{NLDC}-145}$-HER2-vaccinated mice showed vigorous proliferation upon stimulation with recombinant HER2 protein, but not TRP2 protein. A slightly increased proliferation was also detected in the splenocytes from
$\mathrm{scFv}^{\mathrm{NLDC}-145}$-neu-vaccinated mice. In contrast, no evident T-cell proliferation could be observed when mice were vaccinated with untargeted HER2 or neu.

The supernatants of stimulated $\mathrm{T}$ cells were tested for the presence of cytokines by ELISA. Splenocytes obtained from $\mathrm{scFv}^{\mathrm{NLDC}-145}$-HER2-vaccinated mice produced substantial amounts of TNF- $\alpha$ and IFN- $\gamma$ (Figure 3A, right); similarly, a mildly higher level of IFN- $\gamma$ and TNF- $\alpha$ cytokine was also detected in the supernatant from $\mathrm{scFv}^{\mathrm{NLDC}-145}$-neu-vaccinated mice. We did not detect the secretion of IL- 4 and IL-10 cytokines with immunosuppressive activity in all groups.

Next, we evaluated for the induction of HER2-specific $\mathrm{CD}^{+}$and $\mathrm{CD}^{+}{ }^{+}$cells. As shown in Figure 3C, a much higher percentage of $\mathrm{CD}^{+}$and $\mathrm{CD} 8^{+} \mathrm{T}$ cells producing IFN- $\gamma$ and TNF- $\alpha$ was detected upon in vitro restimulation with recombinant HER2 protein in splenocytes from $\mathrm{scFv}^{\mathrm{NLDC}-145}$-HER2-vaccinated mice. These $\mathrm{T}$ cells were HER2-specific since no cells produced these two cytokines upon restimulation with recombinant TRP2 pretein. A representative dot plot was shown in Figure 3B. In addition, splenocytes from $\mathrm{scFv}^{\mathrm{NLDC}-145}$-HER2-vaccinated mice exhibited significantly higher target cell killing than did 

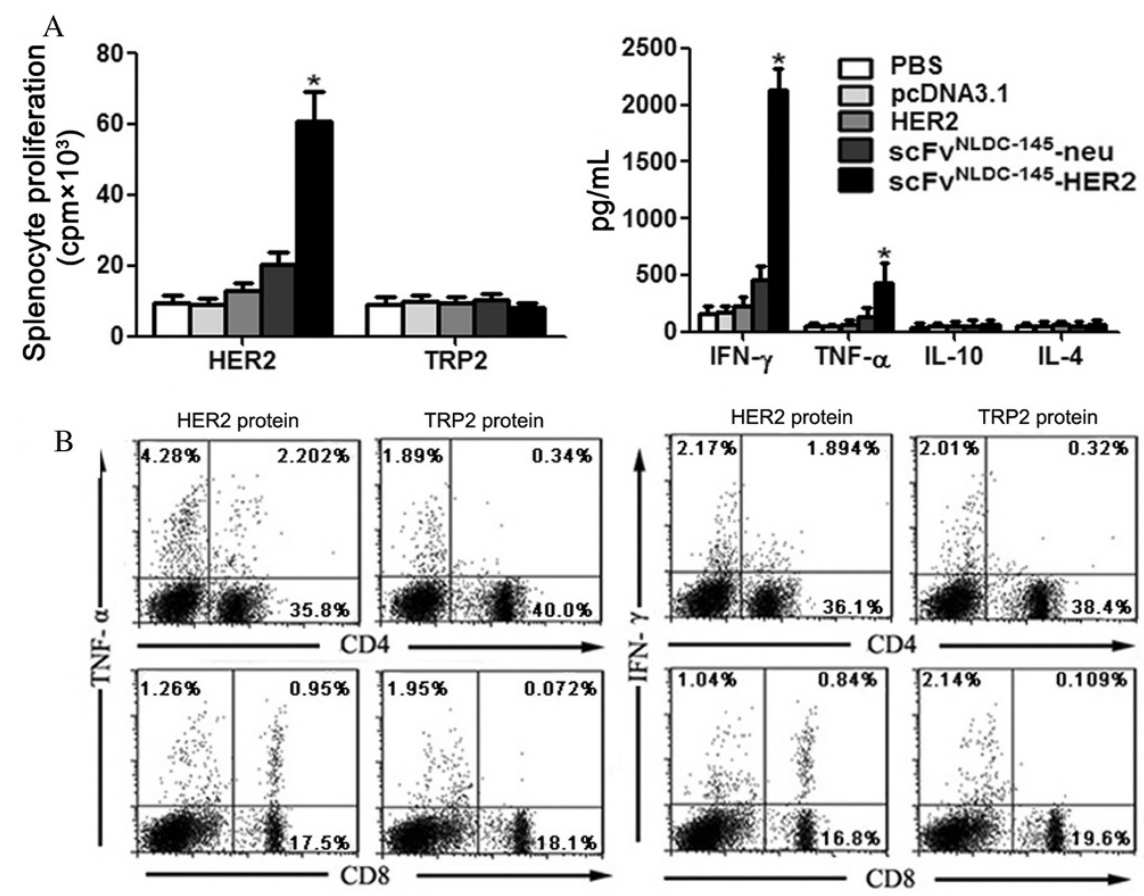

C
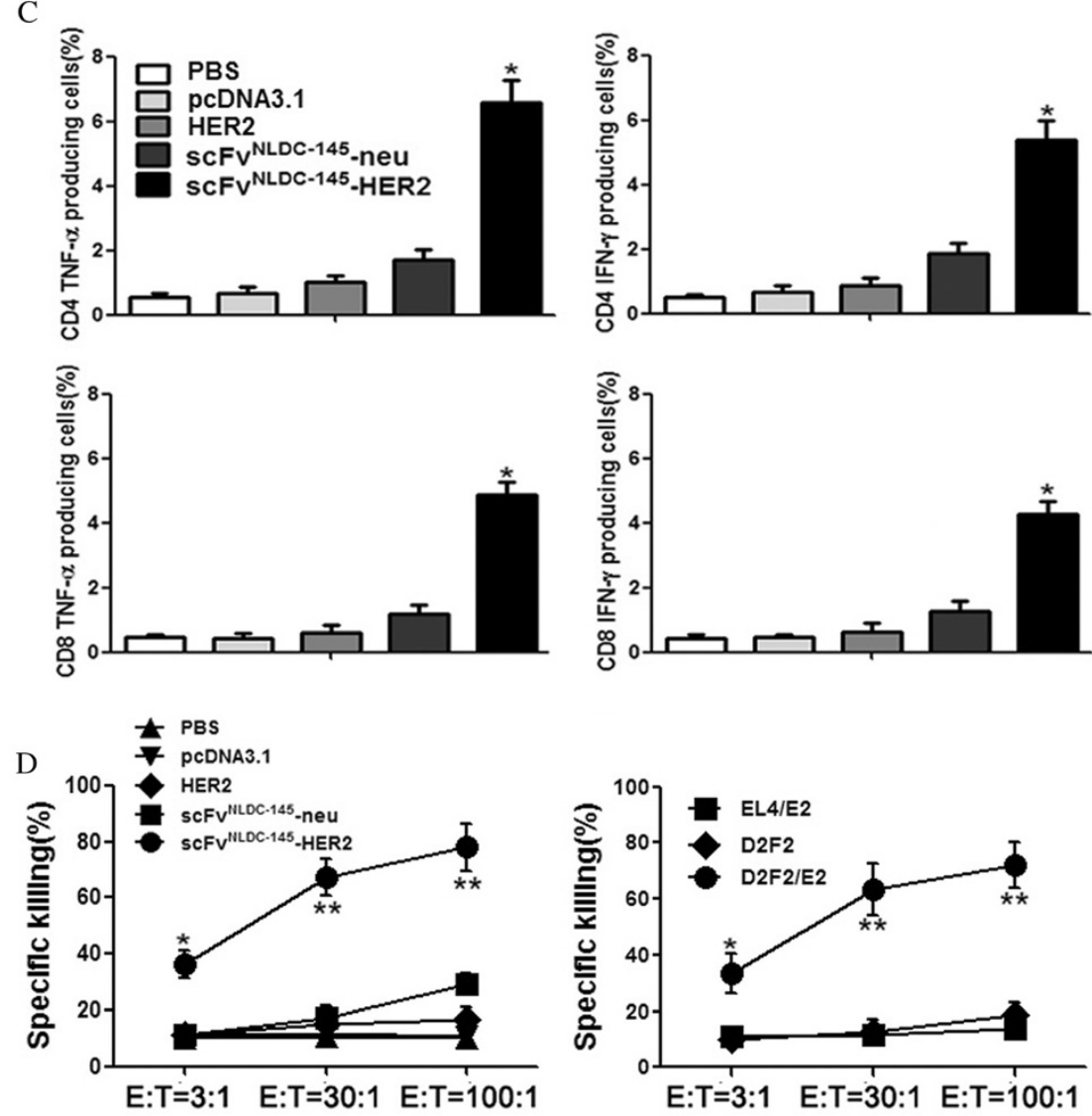

Figure 3 (See legend on next page.) 


\section{(See figure on previous page.)}

Figure 3 Vaccination with scFv ${ }^{\text {NLDC-145 }}$-HER2 induced HER2-specific cellular immune response. BALB/C mice were vaccinated with HER2,

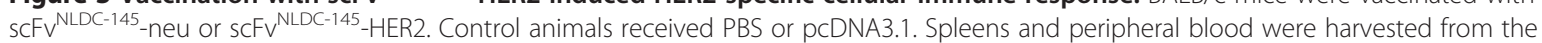
vaccinated animals after two vaccinations. A splenocytes isolated from the vaccinated animals were cultured in the presence of $10 \mu \mathrm{g} / \mathrm{mL}$ recombinant HER2 or TRP2 protein for $4 \mathrm{~d}$ with the addition of $\left[{ }^{3} \mathrm{H}\right]$ thymidine in the last $16 \mathrm{~h}$. T-cell proliferation was determined by [ $\left.{ }^{3} \mathrm{H}\right]$ thymidine incorporation (left panel). Right panel, the supernatant recovered from the assay in left was tested for cytokine production by ELISA. B intracellular staining for IFN- $\gamma$ and TNF- $a$ in splenocytes from the vaccinated animals stimulated with $10 \mu \mathrm{g} / \mathrm{mL}$ recombinant HER2 or TRP2

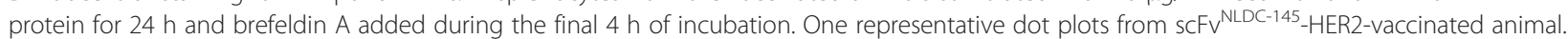
C percentage of $\mathrm{CD}^{+} \mathrm{TNF}-\mathrm{a}^{+}, \mathrm{CD} 4^{+} \mathrm{IFN}-\gamma^{+}, \mathrm{CD} 8^{+} \mathrm{TNF}-\mathrm{a}^{+}$and $\mathrm{CD} 8^{+} \mathrm{IFN}-\gamma^{+}$cells in total CD4 ${ }^{+}$and $\mathrm{CD} 8^{+} \mathrm{T}$ cells from each group are shown. The data are mean percentages \pm SE. D splenocytes were cocultured with D2F2/E2 cells for $5 \mathrm{~d}$. The resultant splenocytes (E) were cocultured for $4 \mathrm{~h}$ with the ${ }^{51} \mathrm{Cr}$-labeled target cells (T) (left panel). Right panel, the restimulated splenocytes from SCFv ${ }^{\mathrm{NLDC}-145}$-HER2 vaccinated mice were also cocultured for $4 \mathrm{~h}$ with the ${ }^{51} \mathrm{Cr}$-labeled D2F2 or EL4/E2 (different gene background control) target cells. Percentages of target cells killing by the splenocytes from the vaccinated mice are shown. Data represent the means of triplicate cultures and are representative of two independent experiments. Bars, SE. *, $\mathrm{P}<0.01,{ }^{* *}, \mathrm{P}<0.001$, sCFv ${ }^{\mathrm{NLDC}-145-H E R 2}$ compared with other groups.

those from other group mice (Figure 3D, left). The specificity of the killing was validated by the inability of the splenocytes to kill parental D2F2 target cells and EL4/E2 target cells with a different $\mathrm{H}-2^{\mathrm{b}}$ background (Figure 3D, right). The cytotoxic effect was mediated by $\mathrm{CD}^{+} \mathrm{T}$ cells, because the killing was inhibited by addition of anti-CD8, but not anti-CD4, antibody (data not shown).

\section{Induction of HER2-specific antibody}

We also evaluated the induction of HER2-specific antibody. As shown in Figure 4A, vaccination with

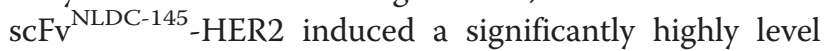
of HER2-specific antibodies specifically binding to recombinant HER2 protein in ELISA assays. Detailed analysis of antibody isotype demonstrated that antibodies induced by $\mathrm{scFv}^{\mathrm{NLDC}-145}$-HER2 vaccine was mainly IgG2a, which was consistent with cytokine profile of splenocytes from $\mathrm{scFv}^{\mathrm{NLDC}-145}$-HER2-vaccinated mice (Figure 4A).

We also tested whether the sera of vaccinated mice contained antibodies binding to "natural" D2F2/E2 cells. As shown in Figure 4B, we detected D2F2/E2-specific antibodies in sera derived from mice vaccinated with $\mathrm{ScFv}^{\mathrm{NLDC}-145}$-HER2, whereas no antibodies were found in other groups. In summary, the results show that $\mathrm{scFv}^{\text {NLDC- }}$ ${ }^{145}$-HER2-vaccinated mice developed antibodies that recognize epitopes expressed by D2F2/E2 cells and thus may also confer protection against tumor growth in vivo.

\section{Therapeutic efficacy of scFv ${ }^{\text {NLDC-145 }}$-HER2 vaccine}

We next evaluated the therapeutic effect of $\mathrm{ScFv}^{\mathrm{NLDC}}$ ${ }^{145}$-HER2 vaccination on established tumors in D2F2/E2 breast tumor model. BALB/c mice were subcutaneously inoculated with D2F2/E2 tumor cells. On day 7, animals with tumors sizing $\sim 40 \mathrm{~mm}^{3}$ were randomized into groups treated with $\mathrm{scFv}^{\mathrm{NLDC}-145}$-HER2 or respective controls. Treatment was repeated once 2 week later. As shown in Figure $5 \mathrm{~A}, \mathrm{scFv}^{\mathrm{NLDC}-145}$-HER2 vaccination substantially slowed tumor development and protected up to $20 \%(2 / 10)$ of the mice from tumor growth at the end of experiment (120 days after tumor inoculation).
Since regulatory $\mathrm{T}$ cells (Treg) have been shown to mediate immune-tolerance towards tumor-antigens in various tumor models, we further tested whether systemic depletion of regulatory $\mathrm{T}$ cells would increase the therapeutic efficacy of DC-targeting vaccine. An approach with intraperitoneal injection of low-dose $(100 \mathrm{mg} / \mathrm{kg})$ cyclophosphamide (CTX) that was successfully applied in various models was utilized this study. As shown in Figure 5B, low-dose CTX injection in the D2F2/E2-bearing mice efficiently depleted Treg almost to the level in tumor-free mice 4 days post-injection, however, no direct killing effect on tumor cells were observed (data not shown). We therefore tested DC-targeted vaccines in combination with Treg depletion by low-dose CTX. As shown in Figure 5C, this combination significantly improved the therapeutic effects of $\mathrm{scFv} \mathrm{NLDC}^{\mathrm{NL}}{ }^{4}$-HER2 vaccine; at the end of experiment, $80 \%(16 / 20)$ mice rejected the established tumor and remaining $4(20 \%)$ mice had stably small tumors $\left(\sim 30 \mathrm{~mm}^{3}\right)$. These tumor-free mice also rejected the rechallenges with the same tumor cells (date not shown). Untargeted DC vaccines failed to exert therapeutic effects although this vaccine in combination with CTX mildly delayed tumor growth. The experiment was repeated with similar results (date not shown). The data indicate that DC-targeting vaccines are able to mount an impressively therapeutic antitumor effect when in combination with systemic Treg depletion.

\section{Antitumoral activity of the scFv ${ }^{\mathrm{NLDC}-145}$-neu DNA vaccine in immunotolerant BALB-neuT mice}

Tumor models based on human HER2-expressing D2F2/E2 cells are useful to assess the basic functionality of cancer vaccines, however, such models do not fully reflect the situation of human cancer usually characterized by immunologic tolerance toward HER2. Therefore, we further tested DC-targeted DNA vaccines in female BALB-neuT mice that represent an immunotolerant model of spontaneous cancer [28]. In these experiments, we used $\mathrm{scFv}^{\mathrm{NLDC}-145}$-neu instead of $\mathrm{scFv}^{\mathrm{NLDC}-145}$-HER2 since the spontaneous tumors developed in BALB-neuT 

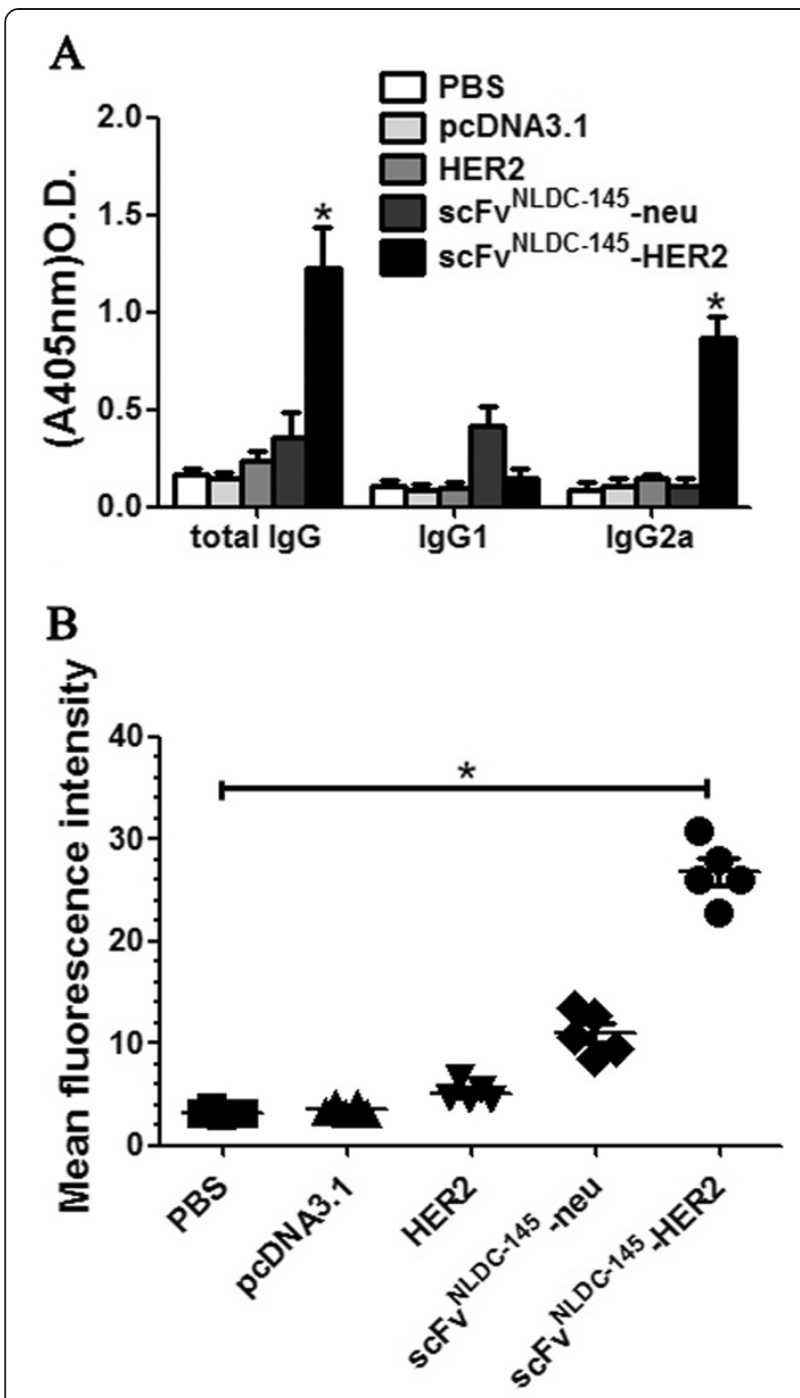

Figure 4 Vaccination with scFv ${ }^{\text {NLDC-145 }}$-HER2 induced HER2specific antibodies. BALB/C mice were vaccinated with HER2, scFv NLDC-145-neu or scFv NLDC-145-HER2. Control animals received PBS or pcDNA3.1. Sera were collected from the vaccinated animals after two vaccinations. A HER2-specific total IgG and IgG subclass (IgG1and lgG2a) antibodies in sera from the vaccinated animals after 1:100 dilution were determined by ELISA. The mean OD405 values of pooled sera from each group ( 5 mice per group) were presented. Bars, SE. The background OD405 of normal mouse sera was $<0.04$. B D2F2/E2 cells were incubated with the immune sera obtained from the vaccinated animals, and surface bound antibodies were detected using FITC-labeled secondary antibodies. Samples were then analyzed by flow cytometry. The data were represented as mean fluorescence intensity. Normal mouse sera served as control. All results were representative of two independent experiments. *, $\mathrm{P}<0.01$, sCFv ${ }^{\mathrm{NLDC}-145}$-HER2 compared with other groups.

mice are driven by constitutively activated rat neu protein.

We first evaluated the preventive efficacy of $\mathrm{scFv} \mathrm{NLDC}^{\mathrm{N}-145}$ neu vaccine using transplantable neu-expressing TUBO tumor model in BALB-neuT mice. BALB-neuT mice received twice $\mathrm{scFv}^{\mathrm{NLDC}-145}$-neu or control vaccination at 14 days interval. One week after last vaccination, the animals were challenged with TUBO tumor cells. As shown in Figure $6 \mathrm{~A}$, the animals receiving $\mathrm{scFv}^{\mathrm{NLDC}-145}$-neu vaccination were significantly protected against a subsequent challenge with TUBO cells. Sixty days after tumor challenge, $90 \%(9 / 10)$ mice in this group remained tumor free and 1 mouse had small tumors $\left(\sim 35 \mathrm{~mm}^{3}\right)$. The experiment was repeated with similar results (data not shown). Mechanistic investigation showed that $\mathrm{scFv}^{\mathrm{NLDC}-145}$-neu induced high levels of neu-specific CTLs and antibodies (Figure 6B,C).

The effect of $\mathrm{scFv}^{\mathrm{NLDC}-145}$-neu vaccination in the prevention of spontaneous mammary tumors that naturally arise in BALB-neuT mice was also evaluated. The $\mathrm{ScFv}^{\mathrm{NLDC}-145}$-neu was given to the mice at week 8 from birth when diffuse atypical hyperplasia is already evident in the mammary glands but before in situ carcinoma is evident [31] and repeated at week 10. Mice in one group also received CTX injection 4 days before the first vaccination. As shown in Figure 6D, scFv ${ }^{\mathrm{NLDC}-145}$-neu/CTX vaccination resulted in a significant prolongation of tumor-free survival. This corresponded with a marked delay ( $\sim$ weeks) in the appearance of macroscopically detectable tumors in the mammary glands of these mice. By week 38, all of the mice that were vaccinated with $\mathrm{ScFv}^{\mathrm{NLDC}-145}$-neu/CTX remained alive. In contrast, by week 26, all of the mice in the control groups had large tumors and required euthanasia. We again observed a mildly protective effect in $\mathrm{ScFv}^{\mathrm{NLDC}-145}$-neu vaccination group, in which the survival of most mice delayed to week 30 .

\section{Discussion}

Although clinical trials have shown that DNA vaccines could elicit immune responses in humans, the protective potency is modest [2]. The reasons for the failure of DNA vaccines to induce potent immune responses in humans have not been elucidated. It is reasonable to assume that low levels of antigen production, inefficient antigen presentation and insufficient stimulation of APC have roles in low potency of DNA vaccine [32].

Our results showed that $\mathrm{scFv}^{\mathrm{NLDC}-145}$ could mediate antigen to be effectively phagocytosed by the DC compared with untargeted antigen in vivo. DEC205 expression is restricted to a subset of DC in mice that are specialized to cross-present exogenous antigens with resultant induction of MHC-I-restricted $\mathrm{CD}^{+}$CTLs and also promote the development of MHC-II-restricted $\mathrm{CD}^{+}$helper T cells [13,33]. Therefore, DEC205-carried antigens can be targeted to $\mathrm{DEC} 205^{+}$cross-presenting $\mathrm{DC}$ in the T-cell zone of spleen, which allows for antigen presentation by $\mathrm{DC}$ to both $\mathrm{CD}_{4}^{+}$and $\mathrm{CD}^{+} \mathrm{T}$ cells and 


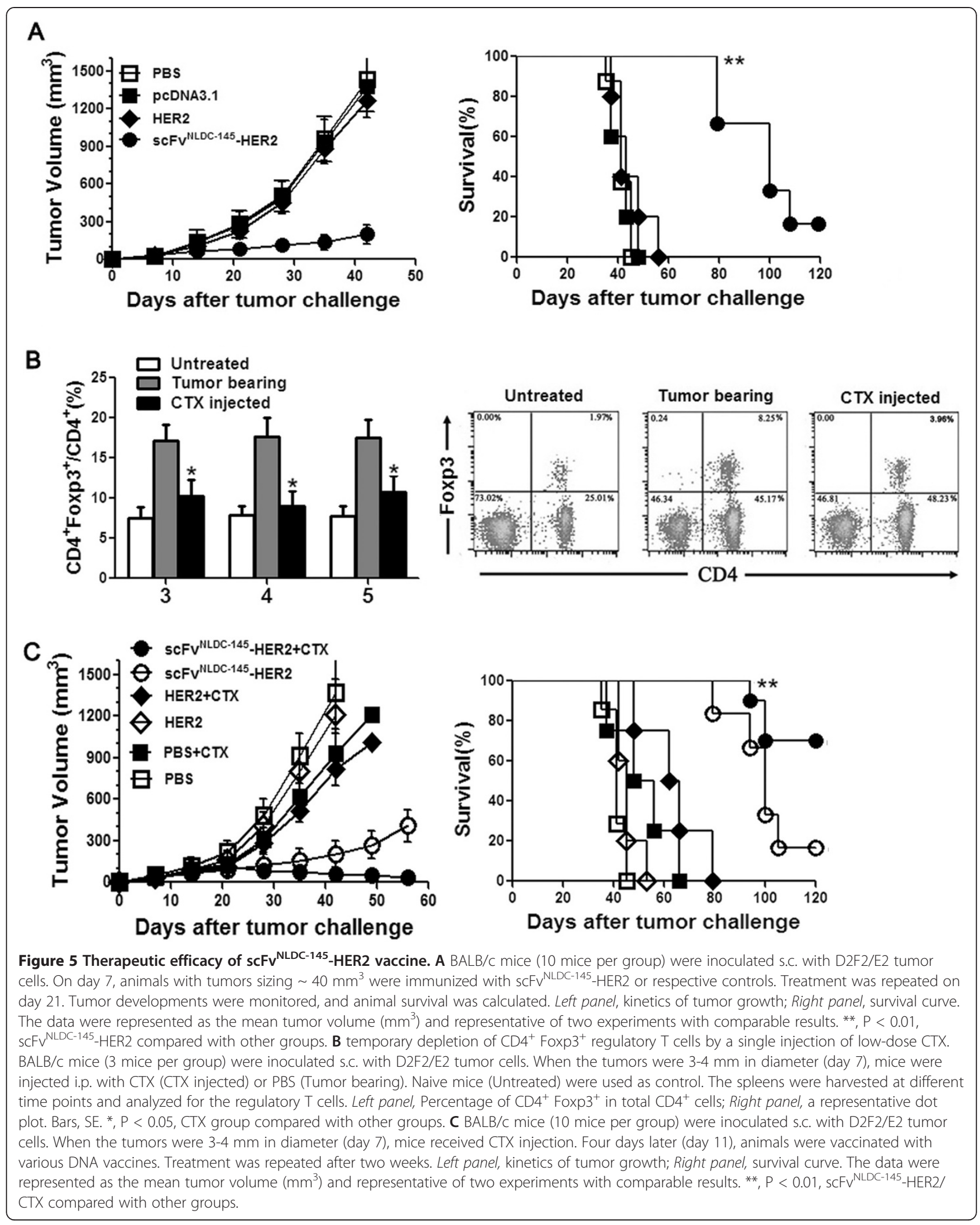



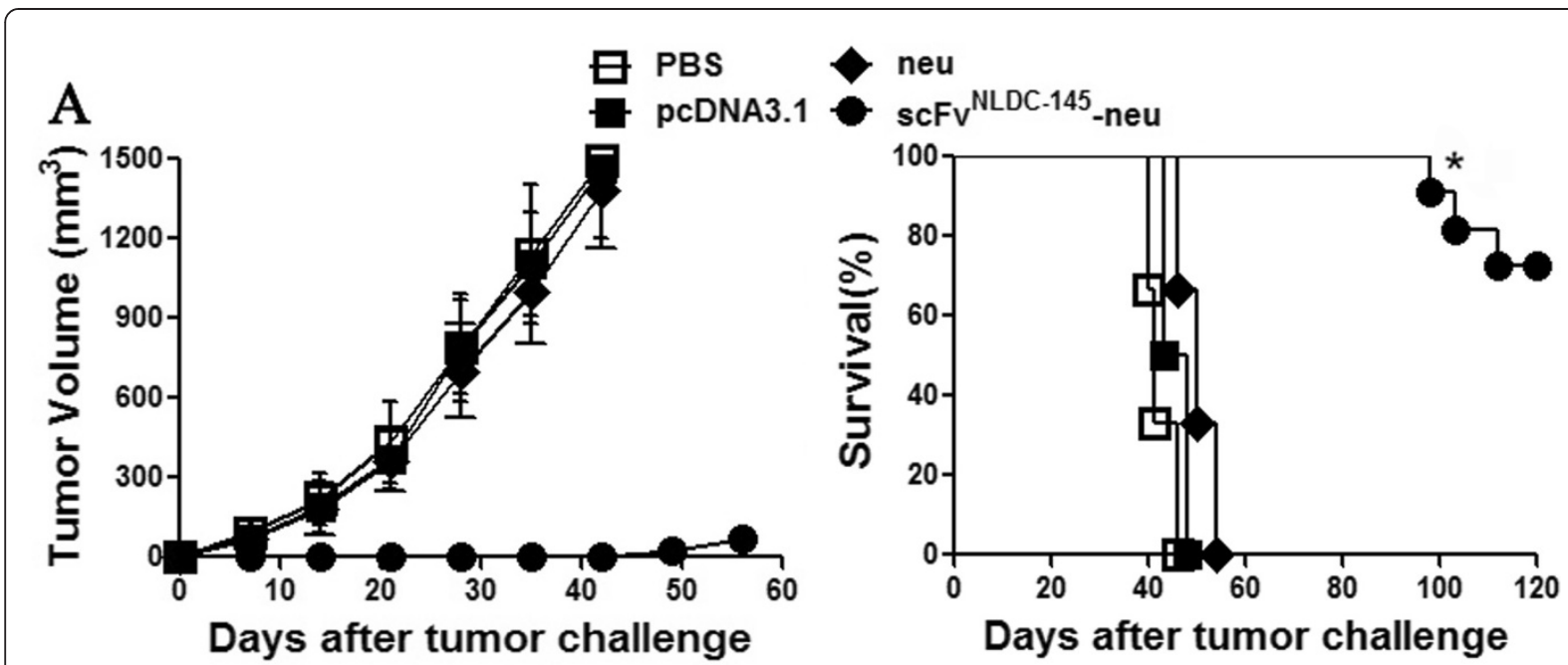

B

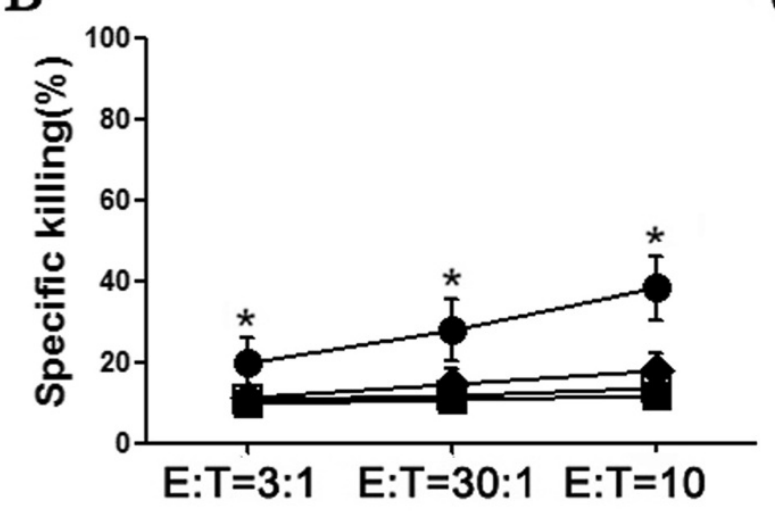

$\mathrm{C}$

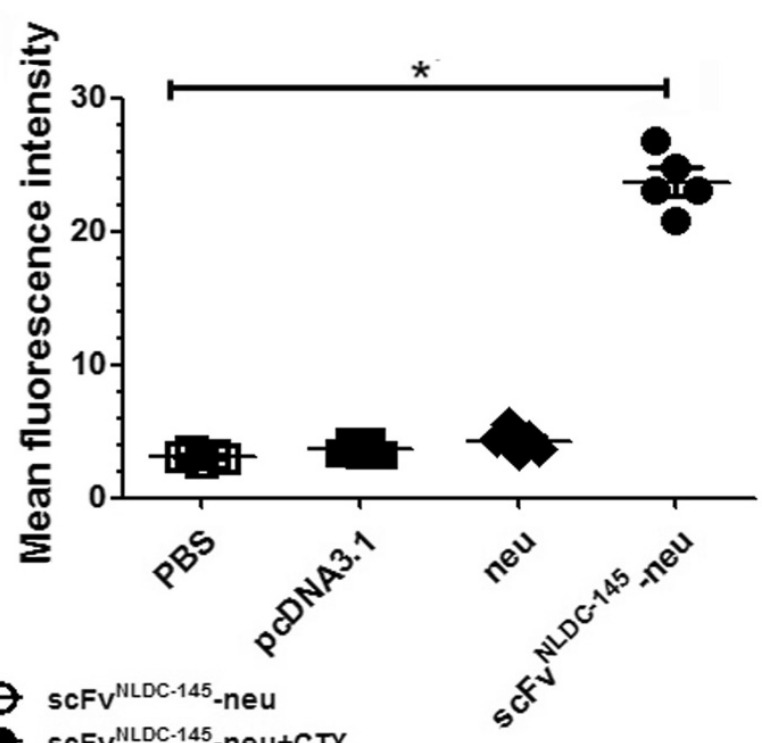

D

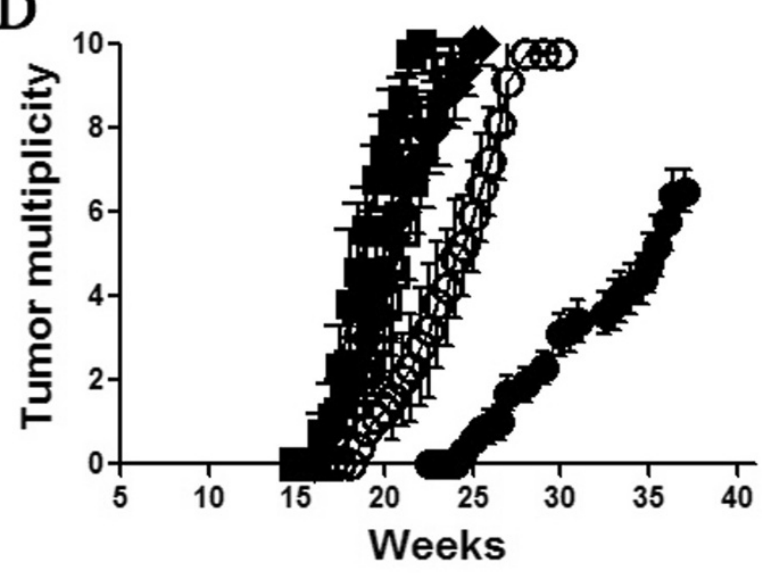

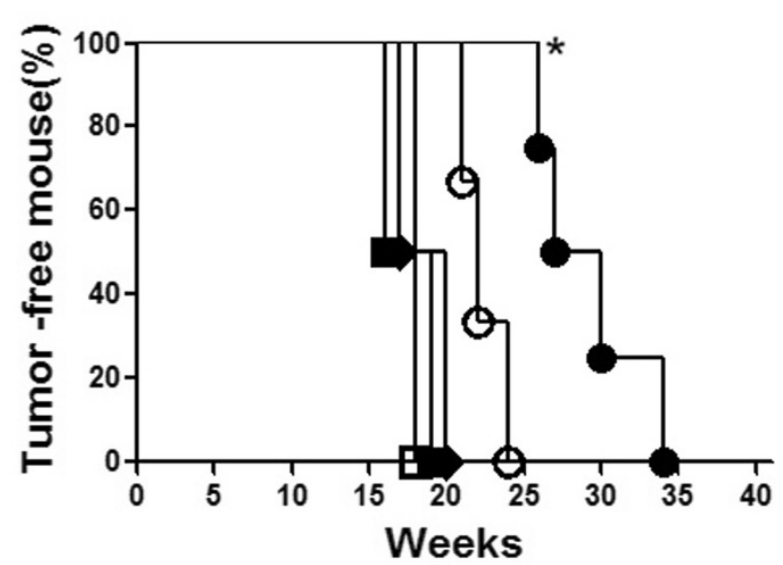


(See figure on previous page.)

Figure 6 Protective effects of scFv ${ }^{\text {NLDC-145 }}$-neu in transgenic BALB-neuT mice. A female BALB-neuT mice (10 mice per group) were vaccinated with neu or SCFV NLDC-145-neu in left hind limb on days -21 and -7 . Control animals received pcDNA3.1 or PBS. On day 0 , mice were inoculated s.c. with neu-expressing TUBO cells in opposite flank. Left panel, kinetics of tumor growth; Right panel, survival curve. ${ }^{*}, \mathrm{P}<0.01$, SCFV ${ }^{N L D C-145}$-neu compared with other groups. B in a separate experiment, splenocytes obtained from the vaccinated mice described above were

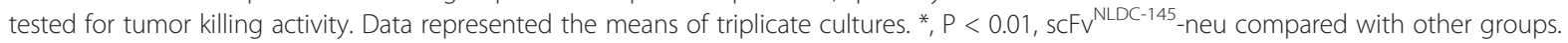
C sera from the vaccinated mice described above were assayed for neu-specific antibodies by flow cytometry. The data were represented as

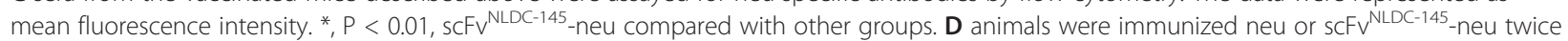

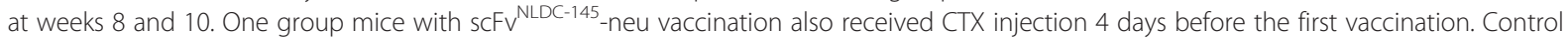
animals received pCDNA3.1 or PBS. Development of mammary tumors was monitored by manual examination of the mammary glands once every week. Measurable masses of $>2$ mm diameter were regarded as tumors. Points, mean number of tumors in each group (tumor multiplicity; left panel) and percentage of tumor-free mice (right panel); bars, SE. All results were representative of two to three independent experiments. *, P $<0.01$, sCFV NLDC-145-neu /CTX compared with other groups.

provides a basis for the induction of a more powerful immune response compared with conventional vaccines. Confirming the pivotal role of $\mathrm{CD}^{+} \mathrm{T}$ cells, HER2specific $\mathrm{CD}^{+}$CTLs specifically lysing HER2-expressing tumor cells were required to protect mice from HER2positive tumor growth since antibody-mediated depletion of these cells abrogated the protective effects conferred by $\mathrm{scFv}^{\mathrm{NLDC}-145}$-HER2 vaccine (Additional file 2: Figure $\mathrm{S} 2$ ), which is also consistent with the previous studies [34,35]. The scFv ${ }^{\mathrm{NLDC}-145}$-HER2 vaccination induced high titer of HER2-specific IgG2a antibodies, indicating Th1-biased immune response. The data are also concordant with two recent studies showing vaccination with DNA vaccines encoding antigen fused to $\mathrm{scFv}{ }^{\mathrm{NLDC}-145}$ generated significantly stronger T-cell and antibody-specific responses compared with that elicited by untargeted vaccines $[10,29]$.

The immune responses induced by $\mathrm{scFv}^{\mathrm{NLDC}-145}$ HER2 vaccination were directed specifically against HER2 antigen as evidenced by protecting against HER2positive D2F2/E2 but not parental HER2-negative D2F2 tumor cells in vaccinated animals. In addition, $\mathrm{scFv}^{\mathrm{NLDC}-}$ ${ }^{145}$-HER2 vaccination induced immunologic memory with vaccinated mice resistant to subsequent rechallenge with D2F2/E2 and D2F2 cells. Presumably, the development of long-term immunologic memory was not only dependent on the HER2 antigen but also on other unidentified antigens of D2F2/E2 tumor. Because antigennegative variants may arise after antigen-positive tumor cells are destroyed, immune responses to additional undefined tumor-associated antigens may be crucial to the ultimate success of vaccination [14,31].

Vaccination with $\mathrm{scFv}^{\mathrm{NLDC}-145}$-HER2 provided up to $20 \%$ of mice from HER2-positive tumor development in the therapeutic setting. The weakly therapeutic potency was possibly due to the insufficiency of local immune responses mounted by targeted DNA vaccine alone since pretreatment of mice with cyclophosphamide significantly increased the protective effects conferred by targeted vaccine with tumor regressed in $80 \%$ of mice. Low-dose CTX is known to selectively deplete Treg cells, with the nadir at day 4 , and recovery to pretreatment levels by day 10 [36]. In addition, CTX has other immunomodulatory effects, including Th2/Th1 switch [37]; induction of type I IFN [38]; and the activation of DC [39]. It has also been reported that CTX pretreatment can remodel the local immune profile with increased IFN- $\gamma$-producing $\mathrm{CD}^{+}$and $\mathrm{CD}^{+}$effector $\mathrm{T}$ cells and decreased Treg cells in tumor microenvironment [40]. Consistent with previous studies [36,40], we observed that CTX treatment significantly decreased both peripheral (Figure 5B) and tumor-infiltrated Treg cells (data not shown), which may consequently promote local vaccine-induced $\mathrm{CD}^{+}{ }^{+} \mathrm{T}$-cell immune responses and induce more potent protection. It needs further investigation to clarify the correlation between local immune response and protective effects induced by targeted vaccine. Considering that reagents are readily available for depletion of Treg cells, our combined strategy holds potential for clinical translation.

Vaccination with scFv ${ }^{\text {NLDC-145 }}$-neu significantly protected against a subsequent challenge with TUBO cells and combination with Tregs ablation markedly delayed the onset of spontaneous mammary carcinomas in BALBneuT mice. The data were consistent with previous studies showing that Treg depletion enabled neu-specific CTL responses after vaccination of neu-transgenic $\mathrm{FVB} / \mathrm{N}$ mice with a cellular vaccine expressing neu and granulocyte macrophage colony-stimulating factor [41] and was able to break tolerance to the immunodominant TYVPANASL epitope [42] and combined with peptide vaccination and adjuvants markedly extended disease-free survival in BALB-neuT mice [43]. Unlike protein-based DC-targeting vaccines, which require the co-injection of additional DC maturation stimuli to induce $\mathrm{T}$ cell responses $[11,13,14]$, DC targeting in a DNA format induces immunity without additional adjuvant [28], possibly because the DNA itself provides some signals for DC maturation [44]. It warrants further study to determine whether the efficacy of DCtargeting vaccines could be further improved by additional stimuli that increase DC numbers and maturation state and/or improve the function of the responding T cells. 


\section{Conclusion}

In summary, our results show that DC-targeting DNA vaccines induce potent immune responses and provoke superior antitumoral effects in mouse breast tumor models; impressively, when combined with Treg depletion, DC-targeting DNA vaccines induce the regression of established tumor in transplantable tumors and significantly retard spontaneous tumor development in immunotolerant BALB-neuT mice. DEC205 is expressed at high levels on a large fraction of DCs in the T cell areas of lymphoid organs, including human lymphoid tissues [45], and this give perspective for its application in human. Since DC-targeting protein vaccines are being evaluated in clinical trials [46], it would be feasible to evaluate DC-targeting DNA vaccination in combination with Treg depletion for cancer treatment.

\section{Additional files}

Additional file 1: Figure S1. Construction and expression of pcDNA3.1sCFV ${ }^{N L D C-145}$-EGFP and pCDNA3.1-EGFP a generated pcDNA3.1-scFv ${ }^{\text {NLDC- }}$ ${ }^{145}$-EGFP by replacing the HER2 fragment with EGFP sequence cloned from pEGFP-N1 plasmid. The pcDNA3.1 vector encoding EGFP without DC-targeting scFv fragment as control. b 293 T cells grown in 24-well plate were transfected with the two expression vectors using Lipofectamine 2000 (invitrogen). Green fluorescent protein GFP was observed by inverted fluorescence microscope (X51-A21PH, OLYMPUS).

Additional file 2: Figure S2. Analysis of cell population responsible for the protective effects by targeted vaccine. Animals ( 5 mice per group) were vaccinated with SCFV ${ }^{N L D C-145}$-HER2 on days -21 and -7 . On day 0 , mice were inoculated s.c. with D2F2/E2 tumor cells. For in vivo depletion of $\mathrm{CD}^{+}, \mathrm{CD}^{+} \mathrm{T}$ cells or CD19 ${ }^{+} \mathrm{B}$ cells, an anti-CD4 $(0.5 \mathrm{mg} / \mathrm{mouse}$; Clone GK1.5), anti-CD8 (0.5 mg/mouse; Clone YTS 169.4), anti-CD19 (0.2 mg/mouse; Clone 1D3) or control (0.5 mg/mouse; Clone 2A3) mAb was injected i.p. on days $-7,-3$ and -1 and repeated weekly later. All mAbs were purchased from BioXcell. Tumor developments were monitored, and animal survival was calculated.

\section{Competing interests}

The authors declare that they have no competing interests.

\section{Authors' contributions}

HFW and JY made substantial contributions to conception and design as well as to the interpretation of the data and drafted the manuscript. JC, YQJ and $\mathrm{WL}$ carried out the experiments. BZ, YH and $\mathrm{HQL}$ contributed to conception, the interpretation of the data and assisted to draft the manuscript. NX conceived of the study, participated in its design and coordination and helped to draft the manuscript. All authors read and approved the final manuscript.

\section{Acknowledgments}

This work is supported by the National Natural Science Foundation of China (No. 30901380/C081501) and the Shanghai Morning Light Program (09CG36).

\section{Author details}

${ }^{1}$ Interventional Oncology, Dahua Hospital, Xuhui District, Shanghai 200237, China. ${ }^{2}$ Interventional Radiology, Suzhou Municipal Hospital, Suzhou, Jiangsu Province 215002, China. ${ }^{3}$ Department of Geriatric Neurology, Brain Hospital Affiliated to Nanjing Medical University, Nanjing 210029, China. ${ }^{4}$ Department of Institution of Hepatobililary and Gastrointestinal Diseases, Second Artillary General Hospital, Beijing 100088, China. ${ }^{5}$ International Joint Cancer Institute, Second Military Medical University, Shanghai 200433, China.
Received: 20 November 2012 Accepted: 31 July 2013

Published: 14 August 2013

\section{References}

1. Zheng C, Juhls C, Oswald D, Sack F, Westfehling I, Wittig B, Babiuk LA, Hurk SDL: Effect of different nuclear localization sequences on the immune responses induced by a MIDGE vector encoding bovine herpesvirus-1 glycoprotein D. Vaccine 2006, 24:4625-4629.

2. Kutzler MA, Weiner DB: DNA vaccines: ready for prime time? Nat Rev 2008, 9:776-788.

3. Wolff JA, Malone R, Williams P, Chong W, Acsadi G, Jani A, Felgner P: Direct gene transfer into mouse muscle in vivo. Science 1990, 247:1465-1468.

4. Casares S, Inaba K, Brumeanu T-D, Steinman RM, Bona CA: Antigen presentation by dendritic cells following immunization with DNA encoding a class II-restricted viral epitope. J Exp Med 1997, 186:1481-1486.

5. Porgador A, Irvine K, Iwasaki A, Barber B, Restifo N, Germain R: Predominant role for directly transfected dendritic cells in antigen presentation to $\mathrm{CD}^{+}$T cells after gene gun immunization. J Exp Med 1998, 188:1075-1082.

6. Akbari O, Panjwani N, Garcia S, Tascon R, Lowrie D, Stockinger B: DNA vaccination: transfection and activation of dendritic cells as key events for immunity. J Exp Med 1999, 189:169-178.

7. Lindquist RL, Shakhar G, Dudziak D, Wardemann H, Eisenreich T, Dustin ML Nussenzweig MC: Visualizing dendritic cell networks in vivo. Nat Immunol 2004, 5:1243-1250.

8. Iwasaki A, Torres CAT, Ohashi PS, Robinson HL, Barber BH: The dominant role of bone marrow derived cells in CTL induction following plasmid DNA immunization at different sites. J Immunol 1997, 159:11-14.

9. Corr M, von Damm A, Lee DJ, Tighe H: In vivo priming by DNA injection occurs predominantly by antigen transfer. J Immunol 1999, 163:4721-4727.

10. Nchinda G, Kuroiwa J, Oks M, Trumpfheller C, Park CG, Huang Y, Hannaman D, Schlesinger SJ, Mizenina O, Nussenzweig MC, Uberla K, Steinman RM: The efficacy of DNA vaccination is enhanced in mice by targeting the encoded protein to dendritic cells. J Clin Invest 2008, 118:1427-1436.

11. Tacken P, de Vries I, Torensma R, Figdor C: Dendritic-cell immunotherapy: from ex vivo loading to in vivo targeting. Nat Rev Immunol 2007, 7:790-802.

12. Carayanniotis $\mathrm{G}$, Barber $\mathrm{BH}$ : Adjuvant-free IgG responses induced with antigen coupled to antibodies against class II MHC. Nature 1987, 327:59-61.

13. Bonifaz LC, Bonnyay DP, Charalambous A, Darguste DI, Fujii S, Soares H, Brimnes MK, Moltedo B, Moran TM, Steinman RM: In vivo targeting of antigens to maturing dendritic cells via the DEC-205 receptor improves T cell vaccination. J Exp Med 2004, 199:815-824.

14. Wei H, Wang S, Zhang D, Hou S, Qian W, Li B, Guo H, Kou G, He J, Wang H, Guo Y: Targeted delivery of tumor antigens to activated dendritic cells via $C D 11 \mathrm{c}$ molecules induces potent antitumor immunity in mice. Clin Cancer Res 2009, 15:4612-4621.

15. Carter RW, Thompson C, Reid DM, Wong SY, Tough DF: Preferential induction of $\mathrm{CD}^{+} \mathrm{T}$ cell responses through in vivo targeting of antigen to dendritic cell-associated C-type lectin-1. J Immunol 2006, 177:2276-2284.

16. He LZ, Crocker A, Lee J, Mendoza-Ramirez J, Wang XT, Vitale LA, O'Neill T, Petromilli C, Zhang HF, Lopez J, Rohrer D, Keler T, Clynes R: Antigenic targeting of the human mannose receptor induces tumor immunity. J Immunol 2007, 178:6259-6267.

17. Tagliani E, Guermonprez P, Sepúlveda J, Lopez Bravo M, Ardavin C, Amigorena S, Benvenuti F, Burrone OR: Selection of an antibody library identifies a pathway to induce immunity by targeting CD36 on steadystate CD8 alpha ${ }^{+}$dendritic cells. J Immunol 2008, 180:3201-3209.

18. Ramakrishna V, Treml JF, Vitale L, Connolly JE, O'Neill T, Smith P, Jones CL, He L, Goldstein J, Wallace PK, Keler T, Endres MJ: Mannose receptor targeting of tumor antigen pme117 to human dendritic cells directs antimelanoma T cell responses via multiple HLA molecules. J Immunol 2004, 172:2845-2852.

19. Tacken PJ, de Vries IJ, Gijzen K, Joosten B, Wu D, Rother RP, Faas SJ, Punt CJ, Torensma R, Adema GJ, Figdor CG: Effective induction of naive and recall T-cell responses by targeting antigen to human dendritic cells via a humanized anti-DC-SIGN antibody. Blood 2005, 106:1278-1285. 
20. Slamon DJ, Godolphin W, Jones LA, Holt JA, Wong SG, Keith DE, Levin WJ, Stuart SG, Udove J, Ullrich A, Press MF: Studies of the HER-2/neu protooncogene in human breast and ovarian cancer. Science 1989, 244:707-712.

21. Klapper LN, Kirschbaum MH, Sela M, Yarden Y: Biochemical and clinical implications of the ErbB/HER signaling network of growth factor receptors. Adv Cancer Res 2000, 77:25-79.

22. Disis ML, Calenoff E, McLaughlin G, Murphy AE, Chen W, Groner B, Jeschke M, Lydon N, McGlynn E, RB L- S, Moe R, Cheever MA: Existent T-cell and antibody immunity to HER-2/neu protein in patients with breast cancer. Cancer Res 1994, 54:16-20.

23. Disis ML, Pupa SM, Gralow JR, Dittadi R, Menard S, Cheever MA: High-titer HER-2/neu protein-specific antibody can be detected in patients with early-stage breast cancer. J Clin Oncol 1997, 15:3363-3367.

24. Disis ML, Gooley TA, Rinn K, Davis D, Piepkorn M, Cheever MA, Knutson KL, Schiffman K: Generation of T-cell immunity to the HER-2/neu protein after active immunization with HER-2/neu peptide-based vaccines. J Clin Oncol 2002, 20:2624-2632.

25. Knutson KL, Schiffman K, Cheever MA, Disis ML: Immunization of cancer patients with a HER-2/neu, HLA-A2 peptide, p 369-377, results in shortlived peptide-specific immunity. Clin Cancer Res 2002, 8:1014-1018.

26. Slamon DJ, Leyland-Jones B, Shak S, Fuchs H, Paton V, Bajamonde A, Fleming T, Eiermann W, Wolter J, Pegram M, Baselga J, Norton L: Use of chemotherapy plus a monoclonal antibody against HER2 for metastatic breast cancer that overexpresses HER2. N Engl J Med 2001, 344:783-792.

27. Foy TM, Bannink J, Sutherland RA, McNeill PD, Moulton GG, Smith J, Cheever MA, Grabstein K: Vaccination with Her-2/neu DNA or protein subunits protects against growth of a Her-2/neu-expressing murine tumor. Vaccine 2001, 19:2598-2606.

28. Boggio K, Nicoletti G, Di Carlo E, Cavallo F, Landuzzi L, Melani C, Giovarelli M, Rossi I, Nanni P, De Giovanni C, Bouchard P, Wolf S, Modesti A, Musiani P, Lollini PL, Colombo MP, Forni G: Interleukin 12-mediated prevention of spontaneous mammary adenocarcinomas in two lines of Her-2/neu transgenic mice. J Exp Med 1998, 188:589-596.

29. Demangel C, Zhou J, Choo AB, Shoebridge G, Halliday GM, Britton WJ: Single chain antibody fragments for the selective targeting of antigens to dendritic cells. Mol Immunol 2005, 42:979-985.

30. Quaglino E, lezzi M, Mastini C, Amici A, Pericle F, Di Carlo E, Pupa SM, De Giovanni C, Spadaro M, Curcio C, Lollini PL, Musiani P, Forni G, Cavallo F: Electroporated DNA vaccine clears away multifocal mammary carcinomas in HER-2/neu transgenic mice. Cancer Res 2004, 64:2858-2864.

31. Wei H, Wang H, Lu B, Li B, Hou S, Qian W, Fan K, Dai J, Zhao J, Guo Y: Cancer immunotherapy using in vitro genetically modified targeted dendritic cells. Cancer Res 2008, 68:3854-3862.

32. Ulmer JB, Wahren B, Liu MA: Gene-based vaccines: recent technical and clinical advances. Trends Mol Med 2006, 12:216-222.

33. Swee LK, Guimaraes CP, Sehrawat S, Spooner E, Barrasa MI, Ploegh HL: Sortase-mediated modification of aDEC205 affords optimization of antigen presentation and immunization against a set of viral epitopes. Proc Natl Acad Sci U S A 2013, 110:1428-1433.

34. Pilon SA, Piechocki MP, Wei WZ: Vaccination with cytoplasmic ErbB-2 DNA protects mice from mammary tumor growth without anti-ErbB-2 antibody. J Immunol 2001, 167:3201-3206.

35. Sloots A, Mastini C, Rohrbach F, Weth R, Curcio C, Burkhardt U, Jäger E, Forni G, Cavallo F, Wels WS: DNA vaccines targeting tumor antigens to B7 molecules on antigen-presenting cells induce protective antitumor immunity and delay onset of HER-2/Neu-driven mammary carcinoma. Clin Cancer Res 2008, 14:6933-6943.

36. Mkrtichyan M, Najjar YG, Raulfs EC, Abdalla MY, Samara R, Rotem-Yehudar R, Cook L, Khleif SN: Anti-PD-1 synergizes with cyclophosphamide to induce potent anti-tumor vaccine effects through novel mechanisms. Eur J Immunol 2011, 41:2977-2986.

37. Matar P, Rozados VR, Gervasoni SI, Scharovsky OG: Th2/Th1 switch induced by a single low-dose of cyclophosphamide in a rat metastatic lymphoma model. Cancer Immunol Immunother 2002, 50:588-596.

38. Proietti E, Greco G, Garrone B, Baccarini S, Mauri C, Venditti M, Carlei D, Belardelli F: Importance of cyclophosphamide-induced bystander effect on $T$ cells for a successful tumor eradication in response to adoptive immunotherapy in mice. J Clin Invest 1998, 101:429-441.
39. Curtsinger JM, Valenzuela JO, Agarwal P, Lins D, Mescher MF: Type I IFNs provide a third signal to CD8 T cells to stimulate clonal expansion and differentiation. J Immunol 2005, 174:4465-4469.

40. Liu P, Jaffar J, Hellstrom I, Hellstrom KE: Administration of cyclophosphamide changes the immune profile of tumor-bearing mice. J Immunother 2010, 33:53-59.

41. Ercolini AM, Ladle BH, Manning EA, Pfannenstiel LW, Armstrong TD, Machiels JP, Bieler JG, Emens LA, Reilly RT, Jaffee EM: Recruitment of latent pools of high-avidity CD8 (+) T cells to the antitumor immune response. J Exp Med 2005, 201:1591-1602.

42. Ambrosino E, Spadaro M, lezzi M, Curcio C, Forni G, Musiani P, Wei WZ, Cavallo F: Immunosurveillance of Erbb2 carcinogenesis in transgenic mice is concealed by a dominant regulatory T-cell self-tolerance. Cancer Res 2006, 66:7734-7740.

43. Nava-Parada P, Forni G, Knutson KL, Pease LR, Celis E: Peptide vaccine given with a Toll-like receptor agonist is effective for the treatment and prevention of spontaneous breast tumors. Cancer Res 2007, 67:1326-1334.

44. Takaoka A, Wang Z, Choi MK, Yanai H, Negishi H, Ban T, Lu Y, Miyagishi M, Kodama T, Honda K, Ohba Y, Taniguchi T: DAI (DLM-1/ZBP1) is a cytosolic DNA sensor and an activator of innate immune response. Nature 2007, 448:501-505.

45. Granelli-Piperno A, Shimeliovich I, Pack M, Trumpfheller C, Steinman RM: Dendritic cell-specific intercellular adhesion molecule 3-grabbing nonintegrin/CD209 is abundant on macrophages in the normal human lymph node and is not required for dendritic cell stimulation of the mixed leukocyte reaction. J Immunol 2005, 175:4265-4273.

46. Galluzzi L, Senovilla L, Vacchelli E, Eggermont A, Fridman WH, Galon J, Sautès-Fridman C, Tartour E, Zitvogel L, Kroemer G: Trial watch: dendritic cell-based interventions for cancer therapy. Oncoimmunology 2012, 1:1111-1134.

doi:10.1186/1471-2172-14-39

Cite this article as: Cao et al.: DNA vaccines targeting the encoded antigens to dendritic cells induce potent antitumor immunity in mice. BMC Immunology 2013 14:39.

\section{Submit your next manuscript to BioMed Central and take full advantage of:}

- Convenient online submission

- Thorough peer review

- No space constraints or color figure charges

- Immediate publication on acceptance

- Inclusion in PubMed, CAS, Scopus and Google Scholar

- Research which is freely available for redistribution 